\title{
CALL FOR PAPERS AND PANELS SOCIAL SCIENCE HISTORY ASSOCIATION - 1984 MEETING
}

The ninth annual meeting of the Social Science History Association will be held October 25-28, 1984 at the Ontario Institute for the Study of Education in Toronto, Canada.

Those wishing to organize a panel, present a paper, chair a panel, serve as a discussant or offer suggestions for the program are invited to contact:

$\begin{array}{ll}\text { Program Committee Chair: } & \text { Co-Chair: } \\ \text { William Claggett } & \begin{array}{l}\text { Marilyn Mavrinac } \\ \text { Department of Political Science } \\ \text { Department of Education } \\ \text { and History }\end{array} \\ \text { University of Mississippi } & \begin{array}{l}\text { Colby College } \\ \text { Waterville, Maine 04901 }\end{array} \\ \text { (601) 232-7401 } & \text { (207) 873-1131, Ext. 2196 }\end{array}$

The full program committee will be announced at the 1983 meeting.

Paper and panel proposals should include a short description of the paper or papers involved and the names, departments and institutional affiliations of all proposed participants. Panels may also be in the form of roundtable discussions. All proposals must be received no later than February 15, 1984.

\section{INTERNATIONAL CONGRESS OF HISTORICAL SCIENCES}

The Sixteenth International Congress of Historical Sciences will take place in Stuttgart, Germany, in August, 1985. The International Economic History Association was initially allotted two half-day sessions in the Congress. The allotment has now been changed, and the I.E.H.A. will have responsibility for five half-day sessions. 
The Executive Committee has designated two subjects, the first to occupy three half-day sessions, and the second two. The first, which had already been decided on in Budapest, is "Religious Intolerance, Economy, and Society" ("Tolerance, Economie, et Société"), on the tricentenary of the revocation of the Edict of Nantes. Professor Emmanuel LeRoy Ladurie, College de France, Paris, and Professor Aldo De Maddalena, Via Francesco Sforza 43, Milan, Italy, have been charged with organizing these sessions.

The second subject is "The Middle East as an Economic Link between the Indian Ocean and Europe, from Medieval to Modern Times." Doctor Murat Cizakca, of the International Institute of Islamic Banking and Economics (Turkish Cyprus) is in charge of these sessions. His address is Apt. 176, Salamis Bay Hotel, Magosa, Mersin 10, via Turkey.

Scholars wishing to participate in these sessions should communicate directly with the convenors.

\section{NINTH INTERNATIONAL ECONOMIC HISTORY CONGRESS 1986}

The Ninth International Economic History Congress will be held in Bern, Switzerland, August 24-29, 1986. There will be four forms of working sessions: Debates and Controversies: five subjects, based on discussion of a general report circulated in advance; Research themes: eight subjects, with discussion of each based on papers circulated in advance; Workshops: informal sessions; and Reports on current international research projects.

The Executive Committee of the International Association has adopted the following program:

\section{Debates and Controversies}

(1) Mountain economies and societies.

(2) The dynamics of urban decline in the late middle ages and early modern times: economic response and social consequences.

(3) The emergence of a world economy, 18th-20th centuries.

(4) Multinational enterprise: international finance, trade and politics in the 20th century. 
(5) The impact of the depression of the 1930s and its relevance for the contemporary world.

\section{Research Themes}

(1) International productivity comparisons and problems of measurement.

(2) Long-term changes in nutrition and standards of living.

(3) The structures of internal (domestic) trade, 15th-19th centuries.

(4) Local and international credit in the Middle Ages.

(5) Oil in the world economy.

(6) Origins and development of public participation in private enterprise.

(7) Technical education and social mobility.

(8) Economic and social history of the ancient world (subject to be specified).

Convenors and rapporteurs for these sessions will be announced subsequently.

The program will be completed at the next meeting of the Executive Committee (April 1984). In addition to many proposals already received, new proposals for workshops (for organizing which the proposers take the responsibility) should be sent to the Secretary General, International Economic History Association, Prof. Pierre Jeannin, Ecole des Hautes Etudes en Sciences Sociales, 54 Boulevard Raspail, 75270 Paris Cedex 06, France, before February 29, 1984. 